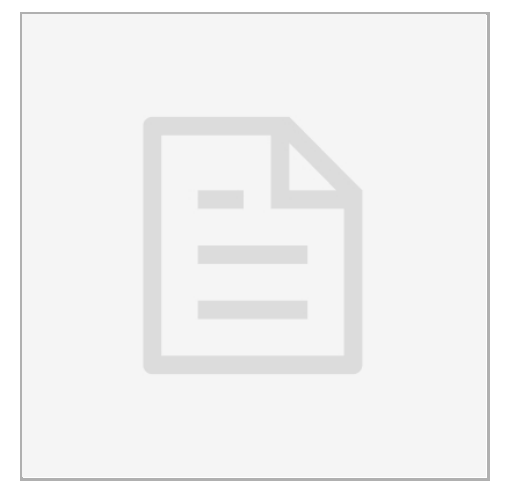

\title{
(3) Plaque PCR
}

Jiaxin $\mathrm{Li}^{1}$

${ }^{1}$ South China University of Technology

OCT 18, 2020

Jiaxin Li

\section{open ठaccess}

\section{DOI:}

dx.doi.org/10.17504/protocol s.io.bni9mch6

Protocol Citation: Jiax in Li 2020. Plaque PCR.

protocols.io

https://dx.doi.org/10.17504/p

rotocols. io. bni9mch6

License: This is an open access protocol distributed under the terms of the Creative Commons Attribution License, which permits unrestricted use, distribution, and reproduction in any medium, provided the original author and source are credited

Protocol status: Working We use this protocol and it's working

Created: Oct 18, 2020

Last Modified: Oct 18, 2020

\section{PROTOCOL integer ID:}

43329

1 Mark independent plaques on the back of the Petri dish with a black pen. Take 6 points in a plate and try to take points randomly and evenly. 
$2 \quad$ Take $241.5 \mathrm{ml}$ EP tubes.

A) Add $200 \mu \mathrm{l}$ SM Buffer per tube

B) Add $2 \mu$ l chloroform to each tube

\section{Sampling}

3 Suck out the plaque just spotted with the pipette

$4 \quad$ Put into the prepared EP tube.

5 Open the metal bath to 95 degrees for lysis of the phage

6 Place the EP tube at room temperature for one hour to dissolve the sample sufficiently and mix several times during the period.

\section{PCR system}

$7 \quad$ KOD FX 20ul system

8 Add $18.4 \mu \mathrm{l}$ to each tube (1.6 $\mu$ l template is needed)

9 After an hour, put the EP tube in a metal bath and heat it for 10 minutes. 
10 Centrifugation for $5 \mathrm{~min}, 12,000 \mathrm{rpm}$

11 Take 1.6ul supernatant from EP tube and add it to new EP tube.

12 Centrifuge the EP tube briefly with a centrifuge.

13 Place in PCR instrument. 